\title{
Differential Autoreceptor Control of Somatodendritic and Axon Terminal Dopamine Release in Substantia Nigra, Ventral Tegmental Area, and Striatum
}

\author{
Stephanie J. Cragg and Susan A. Greenfield \\ University Department of Pharmacology, Oxford University, Oxford OX1 3QT, United Kingdom
}

Dopamine (DA) is released from somatodendritic sites of neurons in the substantia nigra pars compacta (SNc) and ventral tegmental area (VTA), where it has neuromodulatory effects. The aim of this study was to evaluate the role of $D_{2}$ autoreceptor inhibition in the regulation of this somatodendritic release in each region. Fast cyclic voltammetry at carbon fiber microelectrodes was used to measure electrically evoked DA release in vitro. Furthermore, we compared $D_{2}$ regulation of somatodendritic release with the more familiar axon terminal release in caudate putamen (CPu) and nucleus accumbens (NAc). Evoked DA release was TTX-sensitive at all sites. There was significant $\mathrm{D}_{2}$ autoinhibition of DA release in SNc; however, this mechanism was two- to threefold less powerful, as compared with axon terminal release in $\mathrm{CPu}$. In contrast to SNc, somatodendritic release in VTA was not under significant $D_{2}$ receptor control, whereas release in the respective axon terminal region (NAc) was controlled strongly by autoinhibition. Thus, these data indicate that, first, autoinhibition via $D_{2}$ receptors consistently plays a less significant role in the control of somatodendritic than axon terminal DA release, and, second, even at the level of somatodendrites themselves, $\mathrm{D}_{2}$ autoinhibition displays marked regional variation. In the light of previous data indicating that DA uptake processes are also less active in somatodendritic than in terminal regions, these results are interpreted as indicating that DA transmission is regulated differently in somatodendritic zones, as compared with axon terminals, and thus may have different functional consequences.

Key words: somatodendritic release; dopamine; substantia nigra; ventral tegmental area; striatum; $D_{2}$ receptor; autoreceptor
Dopamine (DA) is stored and released from somatodendritic regions of the dopaminergic neurons of the substantia nigra pars compacta (SNc) (A9) and ventral tegmental area (VTA) (A10) (Björklund and Lindvall, 1975; Geffen et al., 1976; Nieoullon et al., 1977). Neuromodulatory actions of somatodendritic DA include autoreceptor inhibition of impulse propagation (Groves et al., 1975; Aghajanian and Bunney, 1977; Lacey et al., 1987, 1990; Mercuri et al., 1989) and heteroreceptor regulation of nondopamine transmission from systems innervating these regions (Gale et al., 1977; Reubi et al., 1978; Waszczak and Walters, 1983, 1984, 1986; Lantin Le Boulch et al., 1991; Aceves et al., 1992; Cameron and Williams, 1993). However, somatodendritic signaling may differ from axon terminal transmission in several respects (see Rice et al., 1997). For example, postsynaptic specializations apposed to dopaminergic dendrites are sparse (Wilson et al., 1977; Reubi and Sandri, 1979; Cuello, 1982; Groves and Linder, 1983), and extrasynaptic plasmalemmal receptors for DA are abundant in the SN and VTA (Sesack et al., 1994; Yung et al., 1995). Furthermore, release is regulated less strictly by DA reuptake in somatodendritic than in striatal axon terminal regions (Cragg et al., 1997). Taken together, these findings suggest that somatodendritic DA signaling relies on extrasynaptic diffusion or "volume transmission" (Fuxe and Agnati, 1991; Nicholson and Rice, 1991). Thus, the time course and sphere of action of somatodendritic

Received April 11, 1997; revised May 14, 1997; accepted May 15, 1997.

S.J.C. was funded by an E. P. Abraham Junior Research Fellowship (St. Cross College, Oxford) and a Goodger Scholarship (Oxford Medical School).

Correspondence should be addressed to Dr. S. J. Cragg, University Department of Pharmacology, Oxford University, Mansfield Road, Oxford OX1 3QT, UK.

Copyright (C) 1997 Society for Neuroscience $0270-6474 / 97 / 175738-09 \$ 05.00 / 0$
DA may differ significantly from a large part of the neurotransmission at axon terminal synapses.

Factors that regulate the extracellular concentration of DA $\left([\mathrm{DA}]_{\mathrm{o}}\right)$ will be pivotal in determining the degree of neuromodulation offered by DA. Defining these factors in SNc and VTA will be a vital step in understanding fundamental features of somatodendritic signaling in these key regions. There are two mechanisms that are central in the control of axon terminal DA neurotransmission in striatum in addition to DA synthesis and the initial response to depolarization: DA uptake via the DA transporter (DAT) (Bull et al., 1990; Cass et al., 1992; Kawagoe et al., 1992; Nicholson, 1995; Giros et al., 1996) and inhibition of release via presynaptic $\mathrm{D}_{2}$-like autoreceptors (Palij et al., 1990; Bull and Sheehan, 1991; Limberger et al., 1991; Trout and Kruk, 1992; Garris et al., 1994). In contrast, DA uptake in somatodendritic regions is markedly less avid (Nissbrandt et al., 1991; Simon and Ghetti, 1993; Cragg et al., 1997). Furthermore, it is unclear whether autoreceptor inhibition is a factor in the regulation of somatodendritic DA release (Nissbrandt et al., 1985; Kalivas and Duffy, 1991; Nissbrandt and Hjorth, 1992) and how any such mechanism might function in the SNc versus VTA. Such comparison of regional function might be crucial for understanding both the physiology and pathophysiology of midbrain dopaminergic neurons, given the regional susceptibility of these cell groups to neurodegeneration, e.g., in Parkinson's disease (Gibb and Lees, 1991). With the use of fast cyclic voltammetry and carbon fiber microelectrodes, it is possible to measure DA release from adjacent somatodendritic regions (Cragg et al., 1997; Rice et al., 1997). Thus, in this study we compare directly the function of autoreceptor control of evoked DA release between somatoden- 
drites and terminals and between the somatodendritic regions SNc and VTA.

\section{MATERIALS AND METHODS}

Brain slice preparation. Brain slices were prepared as described previously (Cragg et al., 1997; Rice et al., 1997) from male albino guinea pigs $(250-450 \mathrm{gm})$. A block of midbrain or rostral neostriatum was isolated over ice, and slices $400 \mu \mathrm{m}$ thick were cut on a Vibratome (Lancer Series 1000 ) in ice-cold artificial cerebrospinal fluid (HEPES-ACSF), which contained (in mM): $\mathrm{NaCl} 120, \mathrm{NaHCO}_{3} 20$, glucose 10, HEPES acid 6.7, $\mathrm{KCl} 5$, HEPES salt $3.3, \mathrm{CaCl}_{2} 2$, and $\mathrm{MgSO}_{4} 2$, saturated with $95 \%$ / $\mathrm{O}_{2} / 5 \% \mathrm{CO}_{2}$. Slices were maintained in HEPES-ACSF for at least $1 \mathrm{hr}$ before transferral to a recording chamber. The coordinates of midbrain slice taken correspond approximately to A8.0-A8.7 mm anterior (A) to the interaural line, according to the atlas of Smits et al. (1990). All slices were equilibrated with the superfusion medium at $32^{\circ} \mathrm{C}$ for an additional $30 \mathrm{~min}$ before experimentation. The superfusion solution contained (in $\mathrm{mm}$ ): $\mathrm{NaCl} 124, \mathrm{NaHCO}_{3} 26$, glucose 10, $\mathrm{CaCl}_{2} 2.4, \mathrm{KCl} 3.7, \mathrm{MgSO}_{4} 1.3$, and $\mathrm{KH}_{2} \mathrm{PO}_{4} 1.3$, gassed with $95 \% \mathrm{O}_{2} / 5 \% \mathrm{CO}_{2}$. Flow rate was 1.3 $\mathrm{ml} / \mathrm{min}$.

Carbon fiber microelectrodes and fast cyclic voltammetry (FCV). Carbon fiber microelectrodes for FCV were spark-etched to a tip length of 30-50 $\mu \mathrm{m}$ and beveled to a tip diameter of 2-4 $\mu \mathrm{m}$ (MPB Electrodes, London, UK). Electrode calibrations were performed in the recording chamber postexperiment, with $1-5 \mu \mathrm{M}$ DA in Ringer's solution at $32^{\circ} \mathrm{C}$. Calibration solutions were made immediately before use from stock solutions in $0.1 \mathrm{M} \mathrm{HClO}_{4}$. The detection limit for $[\mathrm{DA}]_{\mathrm{o}}$ in situ was 30-40 nM.

Voltammetric measurements were made with a Millar Voltammeter (P.D. Systems, West Moseley, UK) as described previously (Cragg et al., 1997; Rice et al., 1997); the applied waveform was a dual-triangle wave scanning from -0.7 to $+1.3 \mathrm{~V}$ and back versus $\mathrm{Ag} / \mathrm{AgCl}$ (see also Figs. $3,5)$. Scan rate was $800 \mathrm{~V} / \mathrm{sec}$, and the sampling frequency was $4 \mathrm{~Hz}$. All current records illustrated are faradaic currents obtained by electronic subtraction of the background current. Background-subtracted voltammograms were monitored on a Gould 1602 storage oscilloscope and recorded on digital audiotape for analysis with Strathclyde Electrophysiology software. In caudate putamen $(\mathrm{CPu}), y-t$ traces of $[\mathrm{DA}]_{\mathrm{o}}$ versus time were obtained by sampling the current at the DA oxidation peak $(+530 \mathrm{mV}$ vs $\mathrm{Ag} / \mathrm{AgCl})$. In striatum in general, changes in [DA $]_{0}$ can be resolved more readily against time than in midbrain, owing to the greater ratio of signals to background shifts than in midbrain; during stimulation, DA voltammograms are accompanied in part, but followed in large part, by some distortion because of $\mathrm{pH}-$ and $\mathrm{Ca}^{2+}$-dependent changes in background current (Rice and Nicholson, 1989, 1995; Jones et al., 1994; Rice et al., 1994).

Electrical stimulation. Bipolar stimulating electrodes were prepared from Teflon-coated platinum wire as previously described (Cragg et al., 1997; Rice et al., 1997) but with a smaller diameter: bare diameter $50 \mu \mathrm{m}$, coated diameter $75 \mu \mathrm{m}$, tip separation $50 \mu \mathrm{m}$, and a total array size of $\sim 200 \mu \mathrm{m}$. The tips of the bipolar electrode were positioned for surface stimulation as previously described (Cragg et al., 1997; Rice et al., 1997). The two forms of stimulation used were a train of pulses $(0.1 \mathrm{msec}$ pulses, $18 \mathrm{~V}$ ) at either $10 \mathrm{~Hz}$ (see Rice et al., 1997) for 3-4 sec or a "pseudo-one pulse" train (Singer, 1988) at $100 \mathrm{~Hz}$ for $0.1 \mathrm{sec}$. Stimulus pulses were blanked electronically during voltammetric scanning to prevent interference with the FCV signal. The voltammetric microelectrode was inserted 50-100 $\mu \mathrm{m}$ into the tissue directly between the stimulating electrodes.

Drugs and solutions. All drugs and chemicals were obtained from Sigma (Poole, Dorset, UK) except (-)-quinpirole (RBI, St Albans, Herts, UK). Fresh $10,000 \times$ stock solutions of drugs were made daily in deionized $\mathrm{H}_{2} \mathrm{O}$. All solutions were applied by superfusion.

Experimental design and data analysis. Experiments were conducted as described previously (Cragg et al., 1997; Rice et al., 1997): several adjacent recording sites, each separated by $\sim 200 \mu \mathrm{m}$, were sampled within a given slice. Control recordings were made in one hemisphere and compared with the experimental condition recordings from paired sites in the contralateral hemisphere. SNc (A9) is defined as lateral to the accessory optic tract and VTA (A10) as medial. All slices were stained for tyrosine hydroxylase immunoreactivity (TH-ir), as described previously (Hajós and Greenfield, 1993), to confirm correct anatomical placement. All data are expressed as mean $\pm \mathrm{SEM} ; n=$ number of observations. For the figures, each mean percentage of control ("mean $\%$ of control") is the mean from a treatment population represented as a percentage of the mean of the paired control population. Comparisons for differences in means were assessed by paired Student's $t$ tests or Wilcoxon signed ranks test (TTX).

Important considerations for an appropriate stimulation protocol. Autoreceptor activity in vitro is highly sensitive to the duration of the electrical stimulation applied (Singer, 1988): first, different stimulation durations (and intensities) will elicit varying $[\mathrm{DA}]_{\mathrm{o}}$ and therefore a varying concentration-dependent autoreceptor tone; second, there is a threshold time period for autoreceptor activation after transmitter release (Singer, 1988; O'Connor and Kruk, 1991, 1992; Trout and Kruk, 1992; Palij and Stamford, 1993; Wieczorek and Kruk, 1994). For example, a threshold time for activation of $\mathrm{D}_{2}$ receptors in the rat limbic forebrain requires a minimum exposure to DA of 500-1000 msec for an antagonist response to be detectable (Trout and Kruk, 1992). Hence, appropriate stimulus parameters must be selected when determining the role of autoreceptors in the control of transmitter release by application of exogenous agonists or antagonists. Similarly, a technique with appropriate time resolutions, such as FCV, is necessary.

The effects of competitive autoreceptor antagonists can be observed only in the presence of sufficient activation of the autoreceptor population by released DA against which an antagonist can compete. Thus, a stimulation train is required that will exceed any activation threshold time and thus ensure sufficient time- and concentration-dependent receptor activation by endogenous DA. The multisecond stimulation trains (at $10 \mathrm{~Hz}$ ) that are appropriate for eliciting somatodendritic DA release (Cragg et al., 1997; Rice et al., 1997) are suitable for this experiment. On the other hand, the effect of an exogenous autoreceptor agonist requires that activation of the autoreceptor population by the endogenous agonist, DA, is submaximal. Thus, the effect of an exogenous agonist on transmitter release is best examined with minimal endogenous tone at the autoreceptor, i.e., after single-pulse stimulation (Singer, 1988). A singlepulse stimulation results in less endogenous tone at the $\mathrm{D}_{2}$ autoreceptor, as compared with multiple second trains, by two possible mechanisms: first, resultant evoked $[\mathrm{DA}]_{\mathrm{o}}$ is less, and/or, second, the stimulation time is shorter than the threshold time for activation of the DA autoreceptor by endogenous DA. However, a train of pulses is necessary to obtain measurable amounts of $[\mathrm{DA}]_{\mathrm{o}}$ from somatodendritic regions in this system (Rice et al., 1997). Short high-frequency trains, or "pseudo-one pulse" stimulations ( $\leq 100 \mathrm{msec}$; see also Palij and Stamford, 1993), offer a compromise to a single pulse whereby high transmitter efflux is evoked but in a period of time too short to activate the DA autoreceptor (Mayer et al., 1988; Singer, 1988).

FCV at a carbon fiber microelectrode has the appropriate time and space resolutions and sensitivity to resolve DA release at a subsecond sampling rate in response to subsecond stimuli. As a result, the technique is suited ideally to monitoring the role of autoreceptor control of DA release in vitro, which requires subsecond control of stimuli duration and transmitter measurements.

\section{RESULTS}

\section{Identification of DA release}

DA was detected with FCV at a carbon fiber microelectrode after electrical stimulation in SNc, VTA, CPu, or nucleus accumbens (NAc), as described previously (Bull et al., 1990; Palij et al., 1990; Limberger et al., 1991; Trout and Kruk, 1992; Iravani et al., 1996; Cragg et al., 1997; Rice et al., 1997), with either multisecond stimulation trains $(30-40$ pulses at $10 \mathrm{~Hz}$ ) or a pseudo-one pulse stimulation $(10$ pulses at $100 \mathrm{~Hz})$. The identification of extracellular signals evoked by $10 \mathrm{~Hz}$ stimulation as DA and not other monoamines or metabolites was confirmed previously (Cragg et al., 1997; Rice et al., 1997) on the basis of anatomical, electrochemical (see also Figs. 3, 5), and pharmacological criteria. Signals evoked in the same regions in the current study by $100 \mathrm{~Hz}$ pseudo-one pulse stimuli were also identified as DA: DA signals were obtained only in $\mathrm{TH}$-ir regions and had identical oxidation (approximately $+530 \mathrm{mV}$ ) and reduction (approximately -200 $\mathrm{mV}$ ) peak potentials to exogenously applied DA and DA signals obtained previously (see also Figs. 3, 5). No unstimulated levels of DA were detectable. 


\section{Somatodendritic : Axon terminal}

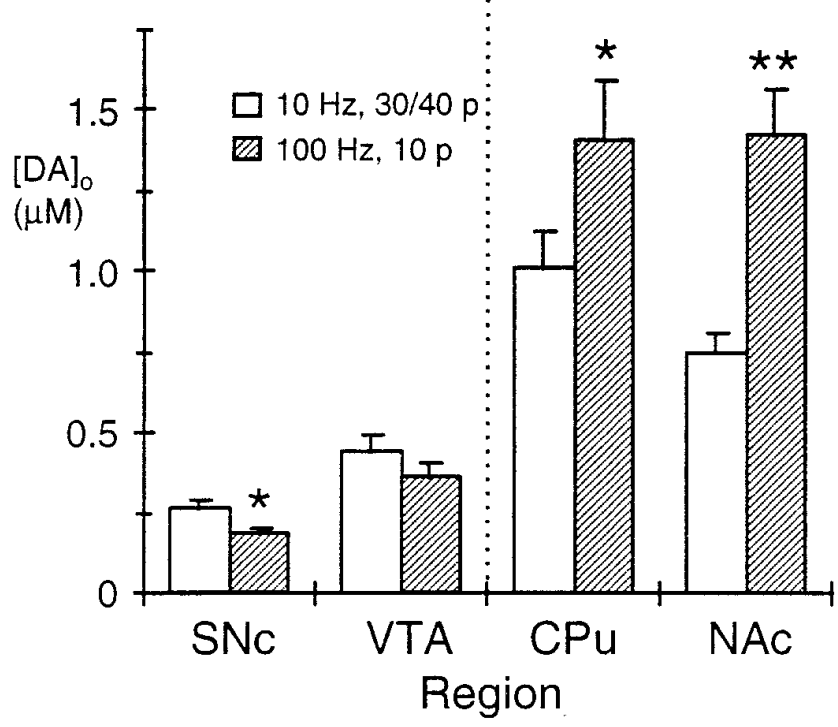

Figure 1. Evoked dopamine release in somatodendritic and axon terminal regions with varying pulse protocol. The graph illustrates the mean maximum evoked [DA] in somatodendritic regions, $S N c$ and $V T A$, and axon terminal regions, $C P u$ and $N A c$, with sustained stimulus trains (10 $\mathrm{Hz}, 30 / 40$ pulses ( $\mathrm{p})$, unfilled bars) versus a pseudo-one pulse stimulus (100 $\mathrm{Hz}, 10$ pulses; filled bars). Evoked $[\mathrm{DA}]_{\mathrm{o}}$ was consistently greater in terminal than in somatodendritic regions. Evoked $[\mathrm{DA}]_{\mathrm{o}}$ was significantly less with the pseudo-one pulse stimulus than with the sustained lower frequency stimulus in $\mathrm{SNc}\left({ }^{*} p<0.05\right)$ and tended toward a similar decrease in $V T A$. In contrast, evoked [DA] $]_{\mathrm{o}}$ was significantly greater with the pseudo-one pulse stimulus than with the sustained lower frequency stimulus in both $C P u\left({ }^{*} p<0.05\right)$ and $N A c\left({ }^{* *} p<0.01\right) ; n=14-38$.

\section{TTX sensitivity of evoked DA release}

Evoked DA release was sensitive to inhibition by TTX $(1 \mu \mathrm{M})$ in all midbrain and axon terminal regions. Somatodendritic DA release in both SNc and VTA (40 pulses, $10 \mathrm{~Hz}$ ) was reduced significantly to $6 \pm 4 \%$ of control release in paired sites from $0.21 \pm 0.02 \mu \mathrm{M}$ (control) to $0.01 \pm 0.01 \mu \mathrm{M}$ (TTX) $(p<0.001$, $n=16)$. Similarly, evoked DA release across $\mathrm{CPu}$ and NAc (30 pulses, $10 \mathrm{~Hz}$ ) was abolished from $0.73 \pm 0.04 \mu \mathrm{M}$ (control) to undetectable levels (TTX) $(p<0.01, n=9)$.

\section{DA release evoked by $10 \mathrm{~Hz}$ stimulation trains}

The mean peak [DA] ovoked by a multisecond $10 \mathrm{~Hz}$ stimulation train in somatodendritic regions was (in $\mu \mathrm{M} \pm \mathrm{SEM}$ ): $0.26 \pm 0.03$, $n=26$ (SNc) and $0.44 \pm 0.05, n=26$ (VTA) (Fig. 1). The mean evoked $[\mathrm{DA}]_{\mathrm{o}}$ released from DA axon terminal regions during a comparable $10 \mathrm{~Hz}$ stimulation train as used previously (Cragg et al., 1997) was (in $\mu \mathrm{M} \pm \mathrm{SEM}$ ): $1.01 \pm 0.11, n=38(\mathrm{CPu})$ and $0.75 \pm 0.06, n=14$ (NAc) (Fig. 1). Thus, with the current stimulation paradigm, the ratios of evoked $[\mathrm{DA}]_{\mathrm{o}}$ in terminal versus somatodendritic regions were approximately fourfold in A9 (CPu vs SNc) and $~ 1.7$-fold in A10 (NAc vs VTA). These ratios are independent of the duration $(<5 \mathrm{sec})$ of the stimulus train in striatal regions, because peak $[\mathrm{DA}]_{\mathrm{o}}$ in both $\mathrm{CPu}$ and NAc is attained within the first second of $10 \mathrm{~Hz}$ stimulation (see Fig. 3b).

\section{DA release evoked by pseudo-one pulse stimulation}

When a shorter train of stimulation, a pseudo-one pulse stimulus (Singer, 1988), was used (100 msec train of 10 pulses at $100 \mathrm{~Hz}$ ), the concentrations of $[\mathrm{DA}]_{\mathrm{o}}$ released in each region were (in $\mu \mathrm{M}$ \pm SEM): $0.18 \pm 0.02, n=16$ (SNc); $0.36 \pm 0.04, n=14$ (VTA); $1.40 \pm 0.19, n=29(\mathrm{CPu})$; and $1.42 \pm 0.14, n=24$ (NAc) (Fig. 1). Compared with evoked $[\mathrm{DA}]_{\mathrm{o}}$ during the multisecond stimulus trains at $10 \mathrm{~Hz},[\mathrm{DA}]_{\mathrm{o}}$ in somatodendritic regions was reduced by 1.5 -fold in SNc $(p<0.05)$ and by 1.2 -fold in VTA, whereas $[\mathrm{DA}]_{\mathrm{o}}$ in terminal regions was enhanced by 1.4 -fold in $\mathrm{CPu}(p<$ $0.05)$ and by 1.9 -fold in NAc $(p<0.01)$. Therefore, with a pseudo-one pulse stimulus train, the ratios of evoked $[\mathrm{DA}]_{\mathrm{o}}$ in terminal versus somatodendritic regions were approximately doubled to eightfold in $\mathrm{A} 9(\mathrm{CPu}$ vs $\mathrm{SNc}$ ) and fourfold in A10 (NAc vs VTA).

\section{$D_{2}$ receptor control of DA release evoked by 10 Hz trains}

In the presence of a supramaximal concentration (see Lacey et al., 1987) of the $\mathrm{D}_{2}$-antagonist sulpiride $(1 \mu \mathrm{M})$, there was a significant increase in mean peak evoked [DA] in SNc to $131 \pm$ $13 \%$ of paired controls from $0.34 \pm 0.04 \mu \mathrm{M}$ to $0.44 \pm 0.05 \mu \mathrm{M}$ $(p<0.05, n=13)$ (Figs. $2 a, 3 a)$. In contrast, evoked [DA] in the adjacent VTA was not affected significantly by sulpiride application at $106 \pm 11 \%$ of paired controls, representing $0.57 \pm 0.05 \mu \mathrm{M}$ in control and $0.61 \pm 0.06 \mu \mathrm{M}$ with sulpiride (Fig. $2 a, n=16$ ).

Evoked DA release in nerve terminal regions in both $\mathrm{CPu}$ and NAc was increased markedly by sulpiride. Maximum evoked $[\mathrm{DA}]_{\mathrm{o}}$ in $\mathrm{CPu}$ was increased significantly to $242 \pm 23 \%$ of paired controls from $1.74 \pm 0.13 \mu \mathrm{M}$ to $4.22 \pm 0.39 \mu \mathrm{M}(p<0.001, n=$ 14) (Figs. $2 a, 3 b)$. In NAc, evoked $[\mathrm{DA}]_{\mathrm{o}}$ was increased significantly to $265 \pm 19 \%$ of paired controls from $0.72 \pm 0.10 \mu \mathrm{M}$ to $1.92 \pm 0.14 \mu \mathrm{M}(p<0.01, n=3)$ (Fig. 2a). The degree of modulation of evoked $[\mathrm{DA}]_{\mathrm{o}}$ by sulpiride in terminal regions $(\mathrm{CPu})$ was significantly greater than in somatodendritic regions (SNc) $(p<0.001$; Student's $t$ test). In addition, the action of sulpiride demonstrated a time dependency: in $\mathrm{CPu},[\mathrm{DA}]_{\mathrm{o}}$ increasingly was enhanced with increasing time of stimulus and was enhanced significantly compared with control only after at least 750 msec stimulation (Fig. 3b).

In somatodendritic regions the $\mathrm{D}_{2}$ receptor agonist quinpirole $(1 \mu \mathrm{M})$ had no inhibitory effect on evoked [DA] $]_{\mathrm{o}}$ (40 pulses, 10 $\mathrm{Hz}$ ) that might be comparable to the action of sulpiride. Evoked $[\mathrm{DA}]_{\mathrm{o}}$ from $\mathrm{SNc}$ in quinpirole was $104 \pm 15 \%$ of paired controls, representing no significant change from $0.19 \pm 0.03 \mu \mathrm{M}$ in control versus $0.20 \pm 0.03 \mu \mathrm{M}$ in quinpirole $(n=13)$ (Figs. $2 b, 3 a)$. Similarly evoked [DA] from VTA was unaffected by quinpirole at $91 \pm 16 \%$ of control: $0.24 \pm 0.03 \mu \mathrm{M}$ versus $0.22 \pm 0.04 \mu \mathrm{M}$ $(n=10)$ (Fig. 2b).

Conversely, in DA terminal regions, there was a significant decrease in evoked [DA $]_{\mathrm{o}}(30$ pulses, $10 \mathrm{~Hz})$ during quinpirole administration in both $\mathrm{CPu}$ and NAc. Maximum evoked [DA] in $\mathrm{CPu}$ was reduced significantly to $31 \pm 2 \%$ of paired controls from $0.58 \pm 0.04 \mu \mathrm{M}$ to $0.18 \pm 0.01 \mu \mathrm{M}(p<0.001, n=25)$ (Figs. $2 b$, $3 b)$. In NAc, evoked [DA] o was reduced significantly to $56 \pm 4 \%$ of paired controls from $0.76 \pm 0.08 \mu \mathrm{M}$ to $0.42 \pm 0.03 \mu \mathrm{M}(p<$ $0.01, n=11$ ) (Fig. $2 b$ ). Whereas the action of sulpiride was increasingly prominent after $750 \mathrm{msec}$ of stimulation, the effect of quinpirole was, in contrast, most pronounced in the initial phase of DA release, before $750 \mathrm{msec}$ of stimulation (Fig. $3 b$ ).

\section{$D_{2}$ receptor control of DA release evoked by a pseudo- one pulse stimulus}

Sulpiride $(1 \mu \mathrm{M})$ had no significant effect on [DA] evoked by pseudo-one pulse stimulation $(10$ pulses, $100 \mathrm{~Hz})$ in any region 


\section{a $\mathrm{D}_{2}$ antagonism}

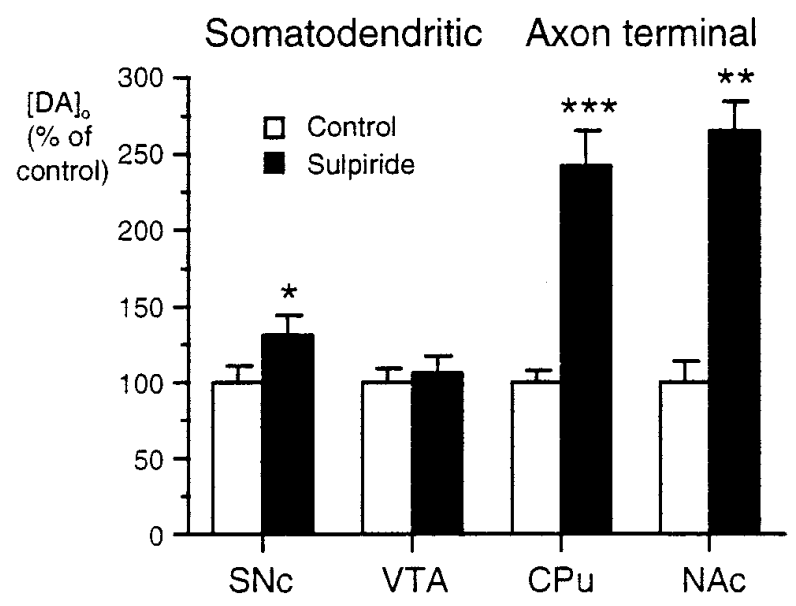

\section{b $\mathrm{D}_{2}$ agonism}

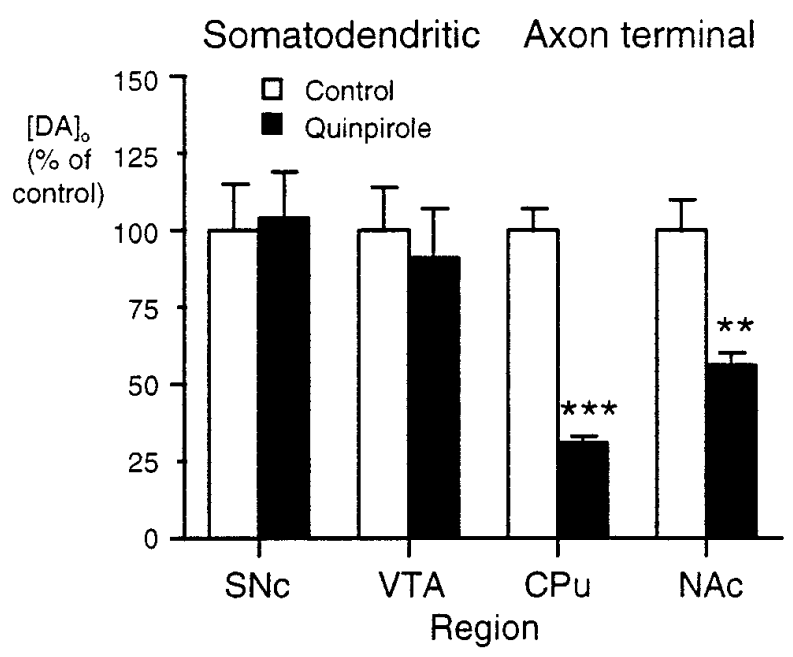

Figure 2. Summary of the effect of $\mathrm{D}_{2}$ receptor modulation on $[\mathrm{DA}]_{\mathrm{o}}$ evoked by a $10 \mathrm{~Hz}$ sustained stimulation in somatodendritic and axon terminal regions. Shown are the effects of $(a) \mathrm{D}_{2}$ antagonism and $(b) \mathrm{D}_{2}$ agonism on evoked $[\mathrm{DA}]_{\mathrm{o}}(10 \mathrm{~Hz}, 30 / 40$ pulses $)$ in somatodendritic regions and terminal fields of the $\mathrm{A} 9$ and $\mathrm{A} 10$ populations. $a$, Sulpiride (1 $\mu \mathrm{M})$ significantly increased [DA] , as compared with controls, in SNc $\left({ }^{*} p<0.05\right)$, but not in VTA $(p>0.05)$. Sulpiride significantly increased $[\mathrm{DA}]_{\mathrm{o}}$, as compared with controls, in both dorsal $C P u(* * * p<0.001)$ and $N A c\left({ }^{*} p<0.01\right)$. The degree of modulation of evoked [DA] $]_{\mathrm{o}}$ in $C P u$ by sulpiride was significantly greater $(p<0.001)$ than in $S N c ; n=3-16$. $b$, Quinpirole $(1 \mu \mathrm{M})$ had no significant effect, as compared with controls, in $S N c(p>0.05)$ or VTA $(p>0.05)$. In contrast, quinpirole significantly reduced $[\mathrm{DA}]_{\mathrm{o}}$, as compared with controls, in both dorsal $\mathrm{CPu}\left({ }^{* * *} p<\right.$ $0.001)$ and $N A c\left({ }^{*} p<0.01\right) ; n$ ranges from 10 to 25 . Data are the mean percentage of control $\pm \mathrm{SEM}$.

tested (Fig. 4a). Evoked [DA] was not affected significantly in the somatodendritic regions, SNc $(93 \pm 5 \% ; 0.17 \pm 0.02 \mu \mathrm{M}$ in control vs $0.16 \pm 0.01 \mu \mathrm{M}$ in sulpiride, $n=7$ ) (Figs. $4 a, 5 a$ ) or VTA $(82 \pm 17 \% ; 0.28 \pm 0.06 \mu \mathrm{M}$ in control versus $0.23 \pm 0.05 \mu \mathrm{M}$ in sulpiride, $n=5$ ) (Fig. $4 a$ ) or in the DA terminal regions, $\mathrm{CPu}$ $(102 \pm 8 \% ; 0.65 \pm 0.05 \mu \mathrm{M}$ in control versus $0.65 \pm 0.05 \mu \mathrm{M}$ in sulpiride, $n=10)$ (Figs. $4 a, 5 b)$ or NAc $(104 \pm 11 \% ; 1.33 \pm 0.15$ $\mu \mathrm{M}$ vs $1.38 \pm 0.15 \mu \mathrm{M}, n=8$ ) (Fig. $4 a$ ).

In contrast, with the use of a pseudo-one pulse stimulation paradigm, $1 \mu \mathrm{M}$ quinpirole subsequently caused a significant decrease in evoked somatodendritic [DA] in SNc to $70 \pm 10 \%$ of paired controls from $0.19 \pm 0.02 \mu \mathrm{M}$ to $0.13 \pm 0.02 \mu \mathrm{M}(p<0.05$, $n=8$ ) (Figs. $4 b, 5 a)$. In contrast, evoked [DA] in VTA remained unaffected by quinpirole at $98 \pm 14 \%$ of paired controls, $0.43 \pm$ $0.05 \mu \mathrm{M}$ in control versus $0.42 \pm 0.06 \mu \mathrm{M}$ in quinpirole $(n=8)$ (Fig. 4b). The most significant changes in one-pulse-evoked $[D A]_{o}$ after quinpirole were seen in axon terminal regions (Fig. $4 b)$. Quinpirole significantly reduced evoked $[\mathrm{DA}]_{\mathrm{o}}$ in $\mathrm{CPu}$ to $29 \pm 2 \%$ of paired controls from $2.48 \pm 0.44 \mu \mathrm{M}$ to $0.71 \pm 0.03 \mu \mathrm{M}$ $(p<0.001, n=12)$ (Figs. $4 b, 5 b)$ and in NAc to $34 \pm 3 \%$ of paired controls from $1.46 \pm 0.13 \mu \mathrm{M}$ to $0.50 \pm 0.04 \mu \mathrm{M}(p<$ 0.001, $n=23$ ) (Fig. 4b).

\section{DISCUSSION}

\section{Characteristics of evoked DA release}

We previously have determined that electrically evoked somatodendritic release of DA from SNc is dependent on extracellular calcium and stimulation frequency, is TTX-insensitive (Rice et al., 1997), and, in contrast to some suggestions (Nirenberg et al., 1996), is not mediated by reversal of the DA uptake transporter (DAT) (Cragg et al., 1997). On the other hand, the DAT is active in the SNc in the reuptake of DA (Cragg et al., 1997). In those studies the TTX insensitivity, coupled with the $\mathrm{Ca}^{2+}$ dependence, suggested that release was stimulated by directly activating voltage-dependent $\mathrm{Ca}^{2+}$ channels, independent of the status of voltage-dependent $\mathrm{Na}^{+}$channels. Previous studies have used TTX sensitivity to address the question of whether somatic $\mathrm{Na}^{+}$ channels, i.e., neuronal firing, are required for somatodendritic release. However, the finding that nonattenuating potentials in DA dendrites also are mediated by voltage-dependent $\mathrm{Na}^{+}$channels (Häusser et al., 1995) indicates that experiments with TTX alone do not address that particular question. In the present study a release mechanism that was TTX-sensitive was recruited by reducing our stimulus current either directly, by reducing applied voltage, or indirectly, by increasing the resistance of the stimulating electrode-solution interface (reduced surface area). Thus, we are now able to study somatodendritic release elicited by a mechanism that is dependent on voltage-dependent $\mathrm{Na}^{+}$ channels.

\section{Comparison of somatodendritic and terminal DA release}

Evoked $[\mathrm{DA}]_{\mathrm{o}}$ was greater from axon terminal than from somatodendritic regions, as previously reported (Iravani et al., 1996; Cragg et al., 1997; Rice et al., 1997), and consistent with tissue DA content (Heeringa and Abercrombie, 1995). Moreover, within a given region, the ratios of peak $[\mathrm{DA}]_{\mathrm{o}}$ released in response to the two types of pulse trains were different in somatodendritic, as compared with terminal, regions. Whereas in both SNc and VTA a sustained $10 \mathrm{~Hz}$ train evoked greater [DA] than the pseudo-one pulse, in $\mathrm{CPu}$ and NAc a sustained $10 \mathrm{~Hz}$ train evoked lower peak $[\mathrm{DA}]_{\mathrm{o}}$ than a pseudo-one pulse. Such a discrepancy arises from a complex interplay of many factors, including the ability to follow depolarization frequency and processes that constrain $[\mathrm{DA}]_{\mathrm{o}}$ during stimulation, such as storage, uptake, and autoinhibition of release. Thus, these data are indicative of a net prevailing difference in such processes at somatodendritic versus terminal levels. In fact, somatodendritic and axon terminal sites may differ in their primary DA storage site (Cuello and Kelly, 1977; Mercer et al., 1979; Wassef et al., 1981; Heeringa and Abercrombie, 1995) (see also Rice et al., 1997), whereas DA 

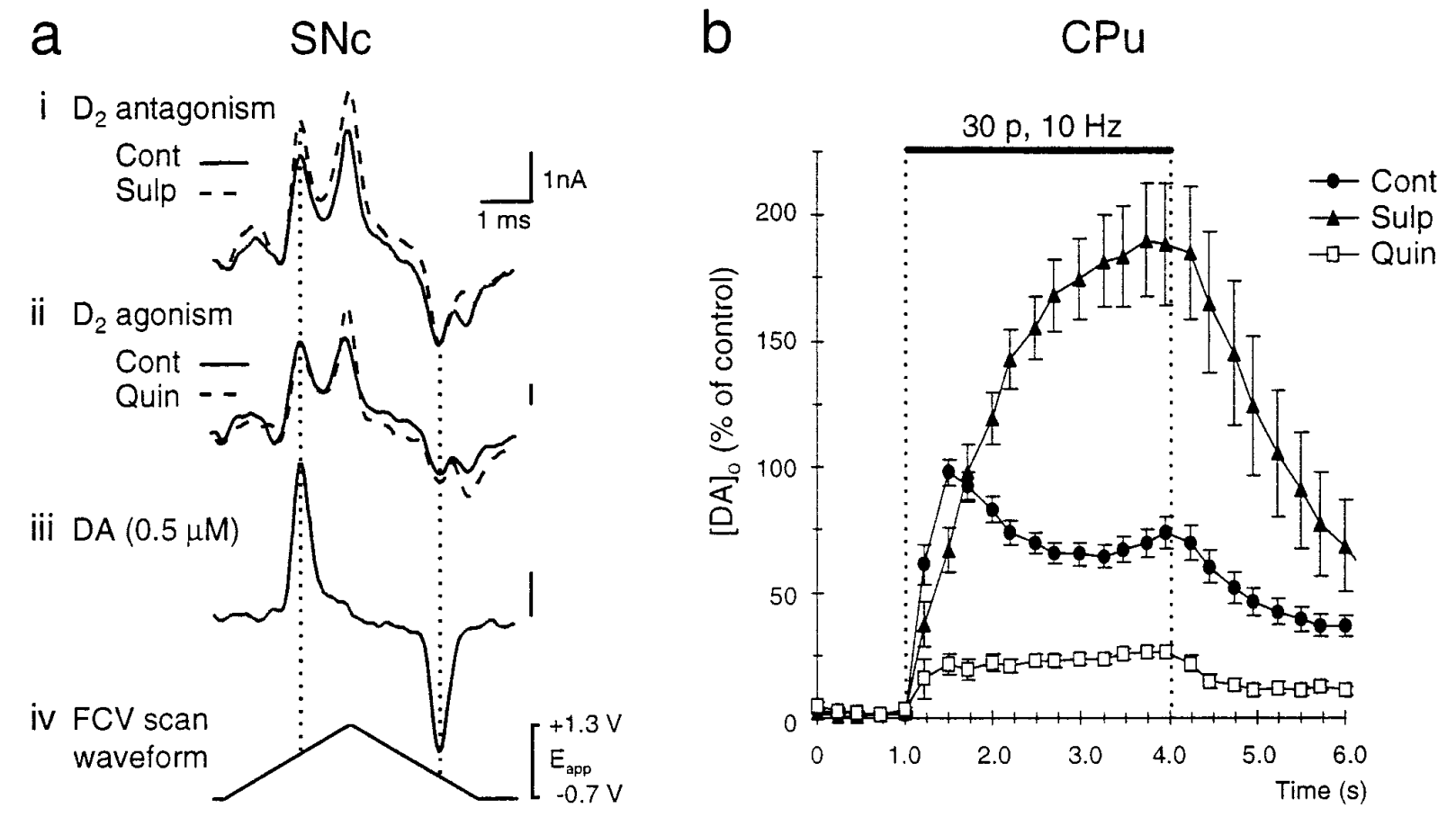

Figure 3. Typical voltammograms and traces of the effect of $\mathrm{D}_{2}$ receptor modulation on $[\mathrm{DA}]_{\mathrm{o}}$ evoked by a $10 \mathrm{~Hz}$ sustained stimulation in $S N c$ and $C P u$. $a$, Typical voltammograms of maximum [DA] obtained during stimulation $(10 \mathrm{~Hz}, 40$ pulses) in $S N c$ in control (Cont, solid line) and with $(i)$ sulpiride (Sulp, $1 \mu \mathrm{M}$ ) or (ii) quinpirole (Quin, $1 \mu \mathrm{M}$; dashed traces). DA oxidation current was increased in the presence of sulpiride and unaffected by the application of quinpirole. The peak oxidation and reduction potentials of $D A$ are indicated by (iii) a DA calibration voltammogram in Ringer's solution at $32^{\circ} \mathrm{C}$ and occur at +530 and $-180 \mathrm{mV}$, respectively, versus $\mathrm{Ag} / \mathrm{AgCl}$ (dotted lines). The voltammograms are scaled to illustrate relative concentrations. Electrode sensitivity to DA was $6.0-16.4 \mathrm{nA} / \mu \mathrm{M}$. Scale bars: $1 \mathrm{nA}$ and $1 \mathrm{msec} . i v$, The applied FCV voltage waveform versus Ag/AgCl. $b, \mathrm{Averaged}$ traces of evoked [DA] o versus time during stimulation $(10 \mathrm{~Hz}, 30$ pulses) in $C P u$. Stimulation was from $t=1.0$ to $t=4.0 \mathrm{sec}$ (solid bar). In control ( $)$, [DA] was maximal at $0.5 \pm 0.25 \mathrm{sec}$ after the start of the stimulus after a fast rise phase and then declined during stimulation. In the presence of $\mathrm{D}_{2}$ antagonism by sulpiride $(\boldsymbol{\Delta})$, the decline phase of $[\mathrm{DA}]_{\mathrm{o}}$ was eliminated and $[\mathrm{DA}]_{\mathrm{o}}$ increased throughout the stimulus duration, reaching a maximum at $t=2.75 \pm$ $0.25 \mathrm{sec}$ after the start of the stimulus. [DA $]_{\mathrm{o}}$ was elevated significantly, as compared with control, only after $0.75 \mathrm{sec}$ of stimulation. In contrast, $\mathrm{D}_{2}$ agonism by quinpirole $(\square)$ was most prominent in the first $0.75 \mathrm{sec}$ of stimulation by eliminating the initial fast rise phase. [DA] increased gradually during the stimulus, reaching a maximum at $t=3.0 \pm 0.25 \mathrm{sec}$ after the start of the stimulus. Data are the mean \pm SEM; times $(s)$ are $\pm 0.25 \mathrm{sec}$; $n=7-26$.

reuptake systems are more active in axon terminal regions (Cragg et al., 1997). Furthermore, as the current data show, there is, indeed, heterogeneity in the $\mathrm{D}_{2}$ receptor control of release.

\section{$D_{2}$ receptor control of axon terminal DA release}

Consistent with previous data (Palij et al., 1990; Bull and Sheehan, 1991; Limberger et al., 1991; Trout and Kruk, 1992; Garris et al., 1994), evoked DA release in $\mathrm{CPu}$ and NAc was regulated strongly by $\mathrm{D}_{2}$ autoreceptor inhibition, as indicated by the marked enhancement of $[\mathrm{DA}]_{\mathrm{o}}$ after $\mathrm{D}_{2}$ receptor antagonism by sulpiride and the reduction of $[\mathrm{DA}]_{\mathrm{o}}$ during $\mathrm{D}_{2}$ agonism by quinpirole. The time course of autoinhibition in $\mathrm{CPu}$ was consistent with a time delay for $\mathrm{D}_{2}$ receptor activation by $\mathrm{DA}$ in vitro. In particular, competitive $\mathrm{D}_{2}$ antagonism by sulpiride was seen only after at least $750 \pm 250 \mathrm{msec}$ of stimulation and not during only a pseudo-one pulse train; in contrast, a competitive agonist action of quinpirole was most prominent during the pseudo-one pulse and before $500-1000 \mathrm{msec}$ of $10 \mathrm{~Hz}$ stimulation despite the greatest evoked $[\mathrm{DA}]_{\mathrm{o}}$ in this period. A comparable delay period has been reported previously for activation of $\mathrm{D}_{2}$ receptors in striatum after DA release (Trout and Kruk, 1992), for $\alpha_{2}$ receptors in bed nucleus of stria terminalis after norepinephrine release (Palij and Stamford, 1993), and for 5-HT $\mathrm{HT}_{1 \mathrm{~A}}$ receptors in dorsal raphe nucleus after 5-HT release (O'Connor and Kruk, 1991, 1992).

\section{$D_{2}$ receptor modulation of somatodendritic DA release in SNc}

Somatodendritic DA release evoked in $\mathrm{SNc}$ was enhanced significantly by $\mathrm{D}_{2}$ receptor antagonism and reduced by $\mathrm{D}_{2}$ receptor agonism during appropriate stimuli. These data indicate directly, for the first time, that $\mathrm{D}_{2}$ receptors are operative as an autoinhibitory mechanism to regulate somatodendritic release. However, $\mathrm{D}_{2}$ autoinhibition of somatodendritic release differs from terminal release both quantitatively and qualitatively. First, the degree of modulation of $[\mathrm{DA}]_{\mathrm{o}}$ by $\mathrm{D}_{2}$ receptors was approximately twofold less in $\mathrm{SNc}$ than in $\mathrm{CPu}$. Second, the action of $\mathrm{D}_{2}$ agents on somatodendritic release was observed only during the stimulation protocol optimized for the treatment. Specifically, the agonist effects of quinpirole in SNc were apparent only when the occupancy of the $D_{2}$ receptor by endogenous transmitter release was minimized with a pseudo-one pulse stimulus, whereas in $\mathrm{CPu}$ an agonist effect was detected even throughout the sustained stimulus. Together, these quantitative and qualitative differences in $\mathrm{D}_{2}$ regulation of somatodendritic and terminal DA release suggest that $\mathrm{D}_{2}$ autoinhibition in $\mathrm{SNc}$ is less effective than in $\mathrm{CPu}$ presumably because of fewer $\mathrm{D}_{2}$ receptors.

Less effective autoinhibition of release, in conjunction with less DA reuptake via the DAT (Nissbrandt et al., 1991; Simon and Ghetti, 1993; Cragg et al., 1997), will result in an altogether 


\section{a $D_{2}$ antagonism}

\section{Somatodendritic Axon terminal}
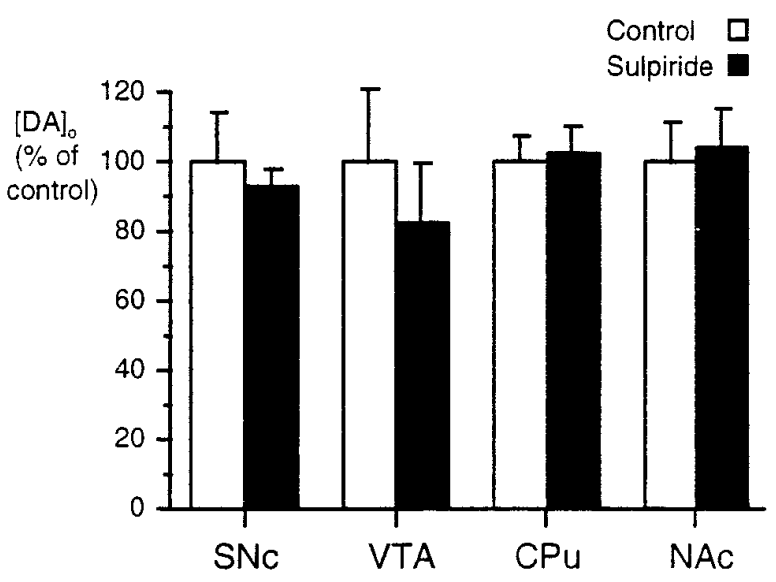

$\mathrm{b} \mathrm{D}_{2}$ agonism

Somatodendritic Axon terminal

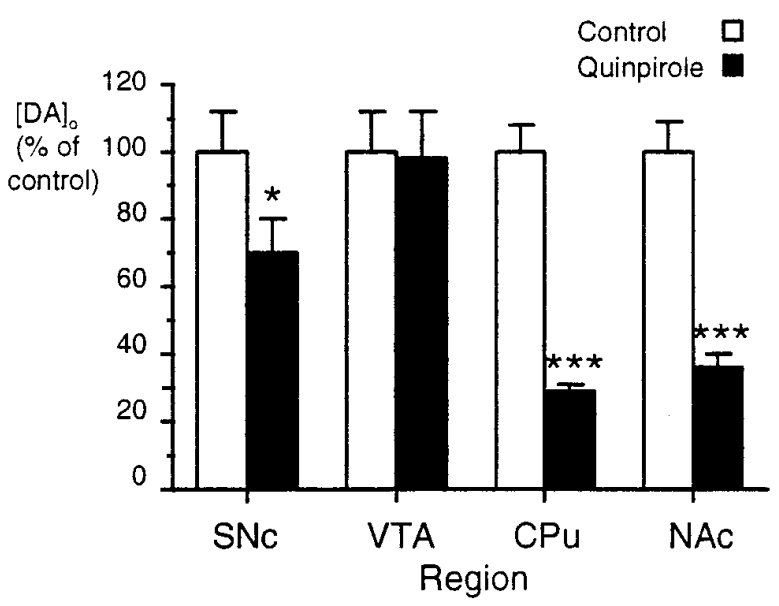

Figure 4. Summary of the effect of $\mathrm{D}_{2}$ receptor modulation on $[\mathrm{DA}]_{\mathrm{o}}$ evoked by a $100 \mathrm{~Hz}$ pseudo-one pulse stimulation in somatodendritic and axon terminal regions. Shown are the effects of $(a) \mathrm{D}_{2}$ antagonism and $(b)$ $\mathrm{D}_{2}$ agonism on evoked $[\mathrm{DA}]_{\mathrm{o}}(100 \mathrm{~Hz}, 10$ pulses $)$ in somatodendritic regions and terminal fields of the A9 and A10 populations. $a$, Sulpiride (1 $\mu \mathrm{M})$ had no significant effect on evoked $[\mathrm{DA}]_{\mathrm{o}}(100 \mathrm{~Hz}, 10$ pulses $)$ in either of the somatodendritic regions $S N c$ or $V T A$ or the terminal fields $C P u$ or $N A c$ of the A9 or A10 system ( $p>0.05$ ); $n$ ranges from 5 to 10 . $b$, Quinpirole $(1 \mu \mathrm{M})$ significantly reduced evoked $[\mathrm{DA}]_{\mathrm{o}}$, as compared with controls, in $S N c\left({ }^{*} p<0.05\right)$ but had no effect in $V T A(p>0.05)$. In contrast, quinpirole significantly reduced $[\mathrm{DA}]_{\mathrm{o}}$, as compared with controls, in both dorsal $C P u\left({ }^{* * *} p<0.001\right)$ and $N A c\left({ }^{* * *} p<0.001\right) ; n=$ $8-23$. Data are the mean percentage of control \pm SEM.

different regulation of $[\mathrm{DA}]_{\mathrm{o}}$ in somatodendritic and axon terminal regions. Such functional variation, together with the differing anatomical constraints in these regions, e.g., sparse postsynaptic specializations in dendritic zones (Wilson et al., 1977; Cuello, 1982; Groves and Linder, 1983) and extrasynaptic location of DA receptors in the SNc and VTA (Sesack et al., 1994; Yung et al., 1995), support the notion that the neuromodulatory actions of somatodendritic release of DA differ in time course and sphere of influence from those of more familiar axon terminal release (Groves and Linder, 1983; Elverfors and Nissbrandt, 1991) (see also Rice et al., 1997).

\section{$D_{2}$ receptor modulation of somatodendritic DA release in VTA}

Surprisingly, in contrast to SNc (A9), evoked [DA] $]_{\mathrm{o}}$ in the adjacent somatodendritic region, the VTA (A10), was unaffected by both sulpiride and quinpirole, irrespective of the stimulus. These observations suggest that $\mathrm{D}_{2}$ autoinhibition plays no part in regulating evoked DA release in VTA. However, this finding does not hold for the A10 path per se: DA release in the terminal region (NAc) is controlled strongly by autoinhibition, as demonstrated by other researchers (Bull and Sheehan, 1991; Trout and Kruk, 1992; Garris et al., 1994), and confirmed here. Although these findings in VTA are consistent with those of Iravani et al. (1996), who similarly failed to detect any $\mathrm{D}_{2}$ autoinhibition of evoked DA release, release in that study was TTX-insensitive, i.e., evoked by a mechanism that was uncoupled from some ionic mechanisms of regulation of membrane potential and thus also likely to be uncoupled from any $\mathrm{D}_{2}$ receptor-mediated hyperpolarization. However, in the current study we demonstrate a lack of autoreceptor control of evoked somatodendritic release in VTA within a paradigm of release that is TTX-sensitive and thus also coupled to local membrane potential.

It cannot be discounted that the observed regional heterogeneity in the $\mathrm{D}_{2}$ receptor control of somatodendritic DA release in some manner might be related to the fact that the VTA may contain more distal dendrites than the $\mathrm{SNc}$; many distal dendrites arising from the SNc actually ramify the SN pars reticulata (Björklund and Lindvall, 1975; Fallon and Moore, 1978). On the other hand, the heterogeneity in $\mathrm{D}_{2}$ receptor control is strongly consistent with accumulating evidence of greater expression levels of $\mathrm{D}_{2}$ protein in SNc than in VTA (Bouthenet et al., 1987; Morelli et al., 1988; Sales et al., 1989; Mansour et al., 1990; Le Moine and Bloch, 1991; Hurd et al., 1994). In particular, stronger autoinhibition of release in SNc than in VTA may be attributable to differential $\mathrm{D}_{2}$ receptor expression levels in the two tiers of neurons that comprise the midbrain DA cell groups. Ventral tier neurons found only in ventral SNc (Fallon and Moore, 1978; Gerfen et al., 1985, 1987) have higher expression and protein levels of the $\mathrm{D}_{2}$ receptor than dorsal tier cells found in dorsal $\mathrm{SNc}$ and throughout VTA (Chiodo et al., 1984; Shimada et al., 1992; Blanchard et al., 1994; Hurd et al., 1994; Sanghera et al., 1994; Ciliax et al., 1995; Freed et al., 1995). Similarly, the greater activity of DA uptake process via the DAT in SNc than in VTA (Cragg et al., 1997) might be attributable to the greater expression levels of the DAT in ventral tier cells (Shimada et al., 1992; Blanchard et al., 1994; Hurd et al., 1994; Sanghera et al., 1994; Ciliax et al., 1995; Freed et al., 1995). In any event, reduced autoreceptor control and uptake via the DAT in VTA suggest that released DA may be under a less strict regulation in VTA than in the adjacent SNc. Such regional variation in somatodendritic transmission in VTA and SNc may be important in the differential susceptibility of these cell groups to the pathophysiologies of schizophrenia and Parkinson's disease, respectively.

\section{Conclusions}

In summary, this study demonstrates directly, for the first time, functional $\mathrm{D}_{2}$ autoinhibition of somatodendritic DA release in the SNc. On the other hand, autoinhibitory processes are less important in the regulation of somatodendritic than axon terminal $[D A]_{o}$. In conjunction with a lower activity of DA uptake systems (Cragg et al., 1997), these data suggest that somatodendritic DA transmission thus will differ significantly from axon terminal transmission in both time course and sphere of action. 

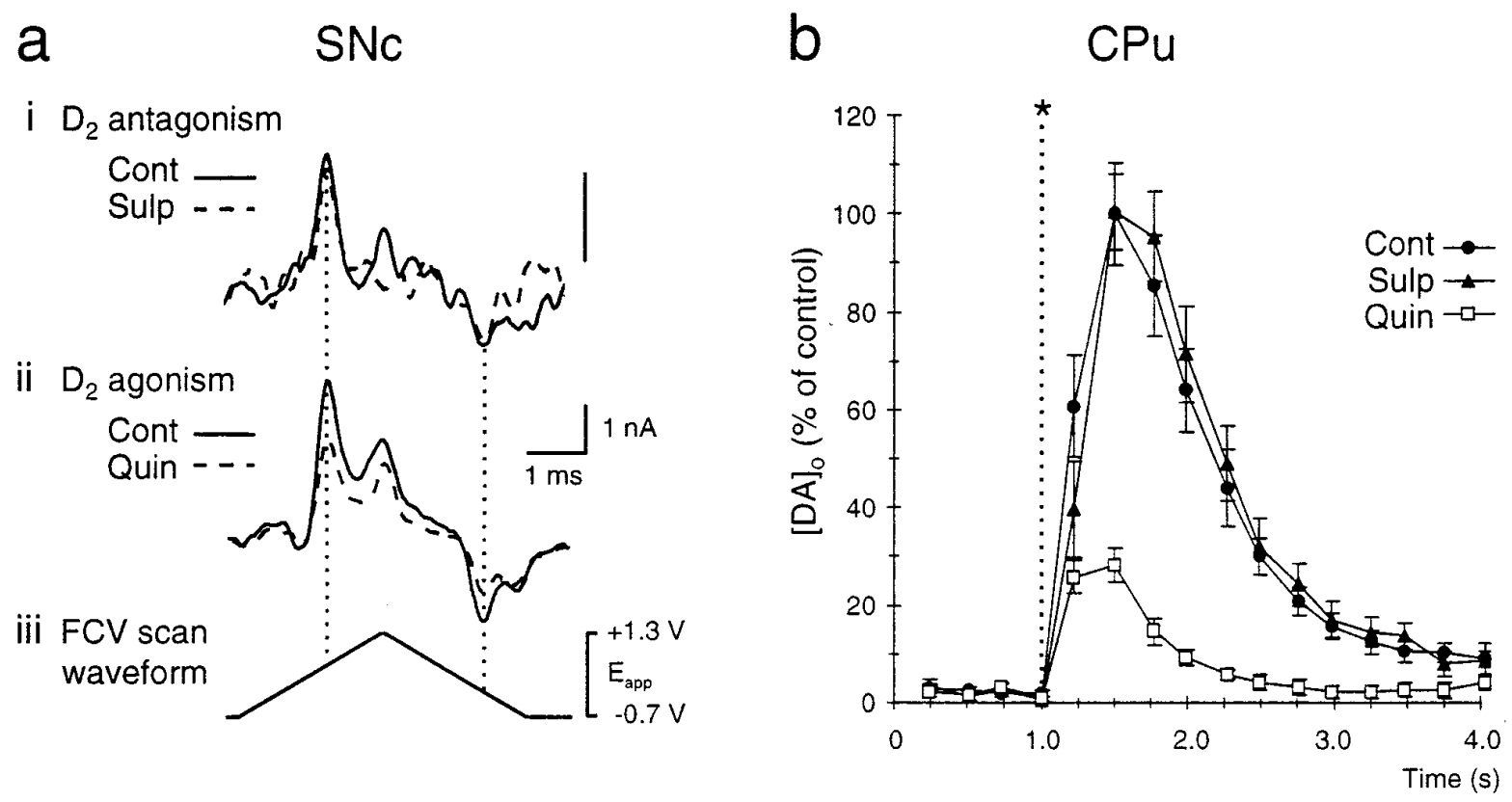

Figure 5. Typical voltammograms and traces of the effect of $\mathrm{D}_{2}$ receptor modulation on $[\mathrm{DA}]_{\mathrm{o}}$ evoked by a $100 \mathrm{~Hz}$ pseudo-one pulse stimulation in $S N c$ and $C P u$. a , Typical voltammograms of maximum [DA $]_{\mathrm{o}}$ obtained during stimulation $(100 \mathrm{~Hz}, 10$ pulses) in $S N c$ in control (Cont, solid line) and with (i) sulpiride (Sulp, $1 \mu \mathrm{M})$ or (ii) quinpirole (Quin, $1 \mu \mathrm{M}$; dashed traces). DA oxidation current was unaffected by the presence of sulpiride but was reduced significantly by quinpirole. Shown are the peak oxidation and reduction potentials of DA at +530 and $-180 \mathrm{mV}$, respectively, versus $\mathrm{Ag} / \mathrm{AgCl}$ (dotted lines). The voltammograms are scaled to illustrate relative concentrations. Electrode sensitivity to DA was $7.8-14.8 \mathrm{nA} / \mu \mathrm{M}$. Scale bars: $1 \mathrm{nA}$ and $1 \mathrm{msec}$. $i v$, The applied FCV voltage waveform versus $\mathrm{Ag} / \mathrm{AgCl}$. $b$, Averaged traces of evoked [DA] versus time during stimulation $(100 \mathrm{~Hz}, 10 \mathrm{pulses})$ in $C P u$. Stimulation was at $t=1.0 \mathrm{sec}$ (asterisk). In control $(\mathbf{O}),[\mathrm{DA}]_{\mathrm{o}}$ reached maximum at $0.5 \pm 0.25 \mathrm{sec}$ after the start of the stimulus that followed a fast rise phase and then declined during stimulation. Control values are derived from controls for both sulpiride and quinpirole experiments. $\mathrm{D}_{2}$ antagonism by sulpiride $(\boldsymbol{\Lambda})$ had no significant effect on $[\mathrm{DA}]_{\mathrm{o}}$ or time to peak maximum. In contrast, $\mathrm{D}_{2}$ agonism by quinpirole $(\square)$ significantly reduced DA release, as compared with controls. Time to peak maximum remained unaffected. Data are the mean \pm SEM; times are $\pm 0.25 \mathrm{sec} ; n=10-22$.

Furthermore, regional variation in $\mathrm{D}_{2}$ autoinhibition of release between somatodendritic regions indicates that these findings not only describe fundamental physiological features of somatodendritic signaling but also may be pivotal for an understanding of the mechanisms underlying the regional pathophysiology of midbrain DA cells.

\section{REFERENCES}

Aceves J, Floran B, Martinez-Fong D, Benitez J, Sierra A, Flores G (1992) Activation of $D_{1}$ receptors stimulates accumulation of gammaaminobutyric acid slices of the pars reticulata of 6-hydroxydopaminelesioned rats. Neurosci Lett 145:40-42.

Aghajanian GK, Bunney BS (1977) Dopamine "autoreceptors": pharmacological characterization by microiontophoretic single-cell recording studies. Naunyn Schmiedebergs Arch Pharmacol 297:1-7.

Björklund A, Lindvall O (1975) Dopamine in dendrites of substantia nigra neurons: suggestions for a role in dendritic terminals. Brain Res 83:531-537.

Blanchard V, Raisman-Vozari R, Vyas S, Michel PP, Javoy-Agid F, Uhl G, Agid Y (1994) Differential expression of tyrosine hydroxylase and membrane dopamine transporter genes in subpopulations of dopaminergic neurons of the rat mesencephalon. Mol Brain Res 22:29-40.

Bouthenet M-L, Martres MP, Sales N, Schwartz JC (1987) A detailed mapping of dopamine $\mathrm{D}_{2}$ receptors in rat central nervous system by autoradiography with [ $\left.{ }^{125} \mathrm{I}\right]$-iodosulpiride. Neuroscience 20:117-155.

Bull DR, Sheehan MJ (1991) Presynaptic regulation of electrically evoked DA overflow in nucleus accumbens: a pharmacological study using FCV in vitro. Naunyn Schmiedebergs Arch Pharmacol 343:260-265.

Bull DR, Palij P, Sheehan MJ, Millar J, Stamford JA, Kruk ZL, Humphrey PPA (1990) Application of FCV to measurement of electrically evoked DA overflow from brain slices in vitro. J Neurosci Methods 32:37-44.

Cameron DL, Williams JT (1993) Dopamine $\mathrm{D}_{1}$ receptors facilitate transmitter release. Nature 366:344-347.
Cass WA, Gerhardt GA, Mayfield RD, Curella P, Zahniser NR (1992) Differences in dopamine clearance and diffusion in rat striatum and nucleus accumbens following systemic cocaine administration. J Neurochem 59:259-266.

Chiodo LA, Bannon MJ, Grace AA, Roth RH, Bunney BS (1984) Evidence for the absence of impulse-regulating somatodendritic and synthesis-modulating nerve terminal autoreceptors on subpopulations of mesocortical dopamine neurons. Neuroscience 12:1-16.

Ciliax BJ, Heilman C, Demchyshyn LL, Pristupa ZB, Ince E, Hersch S, Niznik HB, Levey AI (1995) The dopamine transporter: immunocytochemical characterization and localization in brain. J Neurosci 15:1714-1723.

Cragg SJ, Rice ME, Greenfield SA (1997) Heterogeneity of dopamine release and reuptake in substantia nigra, ventral tegmental area, and striatum. J Neurophysiol 77:863-873.

Cuello AC (1982) Storage and release of amines, amino acids, and peptides from dendrites. In: Chemical transmission in the brain, progress in brain research, Vol 55 (Buijes RM, Pevet P, Sqab DF, eds), pp 205-224. New York: Elsevier.

Cuello AC, Kelly JS (1977) Electron microscopic autoradiographic localization of $\left[{ }^{3} \mathrm{H}\right]$-dopamine in the dendrites of the dopaminergic neurones of the rat substantia nigra in vivo. Br J Pharmacol 59:527-528.

Elverfors A, Nissbrandt H (1991) Reserpine-insensitive dopamine release in the substantia nigra? Brain Res 557:5-12.

Fallon JH, Moore RY (1978) Catecholamine innervation of the basal forebrain. IV. Topography of the dopamine projection to the basal forebrain and neostriatum. J Comp Neurol 180:545-580.

Freed C, Revay R, Vaughan RA, Kriek E, Grant S, Uhl GR, Kuhar MJ (1995) Dopamine transporter immunoreactivity in rat brain. J Comp Neurol 359:340-349.

Fuxe K, Agnati LF, eds (1991) Volume transmission in the brain. New York: Raven.

Gale K, Hong J-S, Guidotti A (1977) Presence of substance P and GABA in separate striatonigral neurons. Brain Res 136:371-375.

Garris PA, Ciolkowski EL, Pastore P, Wightman RM (1994) Efflux of 
dopamine from the synaptic cleft in the nucleus accumbens of the rat brain. J Neurosci 14:6084-6093.

Geffen LB, Jessell TM, Cuello AC, Iversen LL (1976) Release of dopamine from dendrites in rat substantia nigra. Nature 260:258-260.

Gerfen CR, Baimbridge KG, Miller JJ (1985) The neostriatal mosaic: compartmental distribution of calcium binding protein and parvalbumin in the basal ganglia of the rat and monkey. Proc Natl Acad Sci USA 82:8780-8784

Gerfen CR, Herkenham M, Thibault J (1987) The neostriatal mosaic. II. Patch- and matrix-directed mesostriatal dopaminergic and nondopaminergic systems. J Neurosci 7:3915-3934.

Gibb WRG, Lees AJ (1991) Anatomy, pigmentation, ventral and dorsal subpopulations of the substantia nigra, and differential cell death in Parkinson's disease. J Neurol Neurosurg Psychiatry 54:388-396.

Giros B, Jaber M, Jones SR, Wightman RM, Caron MG (1996) Hyperlocomotion and indifference to cocaine and amphetamine in mice lacking the dopamine transporter. Nature 379:606-612.

Groves PM, Linder JC (1983) Dendro-dendritic synapses in substantia nigra: descriptions based on analysis of serial sections. Exp Brain Res 49:209-217.

Groves PM, Wilson CJ, Young SJ, Rebec GV (1975) Self-inhibition by dopaminergic neurons. Science 190:522-529.

Hajós M, Greenfield SA (1993) Topographic heterogeneity of substantia nigra neurons: diversity in intrinsic membrane properties and synaptic inputs. Neuroscience 55:919-934.

Häusser M, Stuart G, Racca C, Sakmann B (1995) Axonal initiation and active dendritic propagation of action potentials in substantia nigra neurons. Neuron 15:637-647.

Heeringa MJ, Abercrombie ED (1995) Biochemistry of somatodendritic dopamine release in substantia nigra: an in vivo comparison with striatal dopamine release. J Neurochem 65:192-200.

Hurd YL, Pristupa ZB, Herman MM, Niznik HB, Kleinman JE (1994) The DA transporter and $\mathrm{DA} \mathrm{D}_{2}$ receptor mRNAs are differentially expressed in limbic- and motor-related subpopulations of human mesencephalic neurons. Neuroscience 63:357-362.

Iravani MM, Muscat R, Kruk ZL (1996) Comparison of somatodendritic and axon terminal dopamine release in the ventral tegmental area and the nucleus accumbens. Neuroscience 70:1025-1037.

Jones SR, Mickelson GE, Collins LB, Kawagoe KT, Wightman RM (1994) Interference by $\mathrm{pH}$ and $\mathrm{Ca}^{2+}$ ions during measurements of catecholamine release in slices of rat amygdala with fast-scan cyclic voltammetry. J Neurosci Methods 52:1-10.

Kalivas PW, Duffy P (1991) A comparison of axonal and somatodendritic DA release using in vivo dialysis. J Neurochem 56:961-967.

Kawagoe KT, Garris PA, Wiedemann DJ, Wightman RM (1992) Regulation of transient dopamine concentration gradients in the microenvironment surrounding nerve terminals in the rat striatum. Neuroscience 51:55-64.

Lacey MG, Mercuri NB, North RA (1987) Dopamine acts on $\mathrm{D}_{2}$ receptors to increase potassium conductance in neurones of the rat substantia nigra zona compacta. J Physiol (Lond) 392:397-416.

Lacey MG, Mercuri NB, North RA (1990) Actions of cocaine on rat dopaminergic neurones in vitro. Br J Pharmacol 99:731-735.

Lantin le Boulch N, Truong-Ngoc NA, Gauchy C, Besson MJ (1991) In vivo release of newly synthesized $\left[{ }^{3} \mathrm{H}\right] \mathrm{GABA}$ in the substantia nigra of the rat: relative contribution of GABA striato-pallido-nigral afferents and nigral GABA neurons. Brain Res 559:200-210.

Le Moine C, Bloch B (1991) Rat striatal and mesencephalic neurons contain the long isoform of the $\mathrm{D}_{2}$ dopamine receptor mRNA. Mol Brain Res 10:283-289.

Limberger R, Trout SJ, Kruk ZL, Starke K (1991) "Real-time” measurement of endogenous DA release during short trains of pulses in slices of rat neostriatum and nucleus accumbens: role of autoinhibition. Naunyn Schmiedebergs Arch Pharmacol 344:623-629.

Mansour A, Meador-Woodruff JH, Bunzow JR, Civelli O, Akil H, Watson SJ (1990) Localization of $\mathrm{D}_{2}$ receptor $m R N A$ and $\mathrm{D}_{1}$ and $\mathrm{D}_{2}$ receptor binding in the rat brain and pituitary: an in situ hybridization receptor autoradiographic analysis. J Neurosci 10:2587-2600.

Mayer A, Limberger N, Starke K (1988) Transmitter release patterns of noradrenergic, dopaminergic, and cholinergic axons in rabbit brain slices during short pulse trains and the operation of presynaptic autoreceptors. Naunyn Schmiedebergs Arch Pharmacol 338:632-643.

Mercer L, del Fiacco M, Cuello AC (1979) The smooth endoplasmic reticulum as a possible storage site for dendritic dopamine in substantia nigra neurones. Experentia 35:101-103.
Mercuri NB, Calabresi P, Bernardi G (1989) The mechanism of amphetamine-induced inhibition of rat substantia nigra compacta neurones investigated with intracellular recording in vitro. Br $\mathrm{J}$ Pharmacol 98:127-134.

Morelli M, Mennini T, Di Chiara G (1988) Nigral dopamine autoreceptors are exclusively of the $\mathrm{D}_{2}$ type: quantitative autoradiography of $\left[{ }^{125}\right.$ I] iodosulpiride and $\left[{ }^{125} \mathrm{I}\right]-\mathrm{SCH} 23982$ in adjacent brain sections. Neuroscience 27:865-870.

Nicholson C (1995) Interaction between diffusion and Michaelis-Menten uptake of dopamine after iontophoresis in striatum. Biophys $\mathrm{J}$ 68:1699-1715.

Nicholson C, Rice ME (1991) Diffusion of ions and transmitters in the brain cell microenvironment. In: Volume transmission in the brain (Fuxe K, Agnati LF, eds), pp 279-294. New York: Raven.

Nieoullon A, Cheramy A, Glowinski J (1977) Release of DA in vivo from cat SN. Nature 266:375-377.

Nirenberg MJ, Vaughan RA, Uhl GR, Kuhar MJ, Pickel VM (1996) The dopamine transporter is localized to dendritic and axonal plasma membranes of nigrostriatal neurons. J Neurosci 16:436-447.

Nissbrandt H, Hjorth S (1992) Dopaminergic neurotransmission in somatodendritic and terminal areas of the rat brain: susceptibility to modulation by $\mathrm{D}_{1}$ and $\mathrm{D}_{2}$ receptors and to axotomy. J Neural Transm Gen Sect 90:13-26.

Nissbrandt H, Pileblad E, Carlsson AJ (1985) Evidence for DA release and metabolism beyond the control of nerve impulses and DA receptors in rat substantia nigra. J Pharm Pharmacol 37:884-889.

Nissbrandt H, Engberg G, Pileblad E (1991) The effects of GBR 12909, a dopamine reuptake inhibitor, on monoaminergic neurotransmission in rat striatum, limbic forebrain, cortical hemispheres, and substantia nigra. Naunyn Schmiedebergs Arch Pharmacol 344:16-28.

O'Connor JJ, Kruk ZL (1991) Frequency dependence of 5-HT autoreceptor function in rat dorsal raphe and suprachiasmatic nuclei studied using fast cyclic voltammetry. Brain Res 568:123-130.

O'Connor JJ, Kruk ZL (1992) Pharmacological characterisation of 5-HT autoreceptors in rat brain slices incorporating the dorsal raphe or the suprachiasmatic nucleus. Br J Pharmacol 106:524-532.

Palij P, Stamford JA (1993) Real-time monitoring of endogenous noradrenaline release in rat brain slices using fast cyclic voltammetry 2 . Operational characteristics of the $\alpha 2$ autoreceptor in the bed nucleus of the stria terminalis: pars ventralis. Brain Res 607:134-140.

Palij P, Bull DR, Sheehan MJ, Millar J, Stamford JA, Kruk ZL, Humphrey PPA (1990) Presynaptic regulation of dopamine release in corpus striatum monitored in vitro in real time by fast-cyclic voltammetry. Brain Res 509:172-174.

Reubi JC, Sandri C (1979) Ultrastructural observations on intercellular contacts of nigral dendrites. Neurosci Lett 13:183-188.

Reubi JC, Emson PC, Jessell TM, Iversen LL (1978) Effects of GABA, DA, and substance $\mathrm{P}$ on the release of newly synthesized ${ }^{3} \mathrm{H}-5-\mathrm{HT}$ from rat SN in vitro. Naunyn Schmiedebergs Arch Pharmacol 304:271-275.

Rice ME, Nicholson C (1989) Measurement of nanomolar dopamine diffusion using low noise perfluorinated ionomer-coated carbon fiber microelectrodes and high-speed cyclic voltammetry. Anal Chem 61:1805-1810

Rice ME, Nicholson C (1995) Diffusion and ion shifts in the brain extracellular microenvironment and their relevance for voltammetric measurements. Neuromethods. In: Voltammetric methods in brain systems, Vol 27 (Boulton A, Baker G, Adams RN, eds), pp 27-79. New York: Wiley.

Rice ME, Richards CD, Nedergaard S, Hounsgaard J, Nicholson C, Greenfield SA (1994) Direct monitoring of dopamine and 5-HT release in substantia nigra and ventral tegmental area in vitro. Exp Brain Res 100:395-406.

Rice ME, Cragg SJ, Greenfield SA (1997) Characteristics of somatodendritic dopamine release from substantia nigra and ventral tegmental area in vitro. J Neurophysiol 77:853-862.

Sales N, Martres MP, Bouthenet ML, Schwartz JC (1989) Ontogeny of dopaminergic $\mathrm{D}_{2}$ receptors in the rat nervous system: characterisation and detailed autoradiographic mapping with [ $\left.{ }^{125} \mathrm{I}\right]$ iodosulpiride. Neuroscience 28:673-700.

Sanghera MK, Manaye KF, Liang CL, Lacopino AM, Bannon MJ, German DC (1994) Low dopamine transporter mRNA levels in midbrain regions containing calbindin. NeuroReport 5:1641-1644.

Sesack SR, Aoki C, Pickel VM (1994) Ultrastructural localization of $\mathrm{D}_{2}$ receptor-like immunoreactivity in midbrain dopamine neurons and their striatal targets. J Neurosci 14:88-106. 
Shimada S, Kitayama S, Walther D, Uhl G (1992) Dopamine transporter mRNA: dense expression in ventral midbrain neurons. Mol Brain Res 13:359-362.

Simon JR, Ghetti B (1993) Is there significant somatodendritic uptake of DA in the SN? Evidence from the weaver mutant mouse. Neurochem Int 22:471-477.

Singer EA (1988) Transmitter release from brain slices elicited by single pulses: a powerful method to study presynaptic mechanisms. Trends Pharmacol Sci 9:274-276.

Smits RPJ, Steinbusch HWM, Mulder AH (1990) Distribution of DAimmunoreactive cell bodies in the guinea-pig brain. J Chem Neuroanat 3:101-123.

Trout SJ, Kruk ZL (1992) Differences in evoked dopamine efflux in rat caudate putamen, nucleus accumbens, and tuberculum olfactorium in the absence of uptake inhibition: influence of autoreceptors. $\mathrm{Br} \mathrm{J}$ Pharmacol 106:452-458.

Waszczak BL, Walters JR (1983) Dopamine modulation of the effects of $\gamma$-aminobutyric acid on substantia nigra pars reticulata neurons. Science 220:218-221.

Waszczak BL, Walters JR (1984) A physiological role for dopamine as modulator of GABA effects in substantia nigra: supersensitivity in 6-hydroxydopamine-lesioned rats. Eur J Pharmacol 105:369-373.

Waszczak BL, Walters JR (1986) Endogenous dopamine can modulate inhibition of substantia nigra pars reticulata neurons elicited by GABA iontophoresis or striatal stimulation. J Neurosci 6:120-126.

Wassef M, Berod A, Sotelo C (1981) Dopaminergic dendrites in the pars reticulata of the rat substantia nigra and their striatal input. Combined immunocytochemical localisation of tyrosine hydroxylase and anterograde degeneration. Neuroscience 6:2125-2139.

Wieczorek WJ, Kruk ZL (1994) Differential action of amphetamine on electrically evoked DA overflow in rat brain slices containing corpus striatum and nucleus accumbens. Brain Res 657:42-50.

Wilson CJ, Groves PM, Fifkova E (1977) Monoaminergic synapses, including dendro-dendritic synapses in the rat substantia nigra. Exp Brain Res 30:161-174.

Yung KK, Bolam JP, Smith AD, Hersch SM, Ciliax BJ, Levey AI (1995) Immunocytochemical localisation of $\mathrm{D}_{1}$ and $\mathrm{D}_{2}$ receptors in the basal ganglia of the rat: light and electron microscopy. Neuroscience 65: $709-730$. 